\title{
Austrolebias paucisquama (Cyprinodontiformes: Rivulidae), a new species of annual killifish from southern Brazil
}

\author{
Juliano Ferrer ${ }^{1}$, Luiz R. Malabarba ${ }^{1}$ and Wilson J. E. M. Costa ${ }^{2}$
}

Austrolebias paucisquama is described from the rio Vacacaí drainage, a tributary to the rio Jacuí, Rio Grande do Sul, Brazil. The new species belongs to the Austrolebias alexandri species-group, by sharing the apomorphic bright blue iridescence and dark gray pectoral fins in males. It is distinguished from other species of this group by having fewer scales around caudal peduncle (12) and fewer dorsal-fin rays in males (17-21). The lack of contact organs on the inner surface of the pectoral fin in males and the color pattern of females - ground color light brownish, sides of body with a variable number of relatively large dark black spots distributed mostly on posterior portion of body - distinguish A. paucisquama from all other species of the genus.

Austrolebias paucisquama, uma nova espécie de peixe anual é descrita da bacia do rio Vacacaí, tributário do rio Jacuí, Rio Grande do Sul, Brasil. A nova espécie pertence ao grupo Austrolebias alexandri, que apresenta duas apomorfias, pontos azuis claros e nadadeiras peitorais cinza escuro nos machos. Distingue-se das outras espécies do grupo pelo reduzido número de escamas ao redor do pedúnculo caudal (12) e pelo menor número de raios na nadadeira dorsal dos machos (17-21). A ausência de órgãos de contato na superfície interior das nadadeiras peitorais nos machos e o padrão de colorido das fêmeas - flancos marrom claro com variável número de pontos pretos relativamente alongados distribuídos principalmente na porção posterior - distinguem A. paucisquama das outras espécies do gênero.

Key words: Systematics, Austrolebias alexandri species-group, Endangered species.

\section{Introduction}

Austrolebias Costa is a genus of annual killifishes whose species inhabit seasonal and temporary pools and swamps formed during the rainy season in southern Brazil, Paraguay, Uruguay, and north and northeast Argentina (Costa, 2006). The genus has been recently phylogenetically redefined by Costa (2006), including the species previously referred to Megalebias Costa. Monophyly of the genus was supported by the following synapomorphies: (a) absence of scales between corner of mouth and anterior portion of preopercular region and ventral portion of opercular region, (b) a deep urohyal, and (c) a dark gray to black infraorbital bar and supraorbital spot. Additional synapomorphies proposed for Austrolebias, but independently acquired by other cynolebiatines were: (a) dorsal and anal fins rounded in males, (b) a long urogenital papilla in males, and (c) a reduced ventral process of the angulo-articular.

Costa (2002) recognized five species as belonging to $A$. alexandri species-group: A. affinis (Amato), A. alexandri (Castello \& Lopez), A. cyaneus (Amato), A. ibicuiensis (Costa) and $A$. periodicus (Costa). In a more recent review, Costa (2006) redefined the group based on the apomorphic dark gray pigmentation of the pectoral fins and the bright blue iridescence in males, and has expanded the group including $A$. duraznensis (García, Scvortzoff \& Hernandéz), A. juanlangi Costa, Cheffe, Salvia \& Litz, A. litzi Costa, A. nigripinnis (Regan) and A. paranaensis Costa. The species A. luzardoi described by Perujo et al. (2005) also belongs to this group.We herein describe a new species of Austrolebias from the rio Vacacaí drainage, a tributary of the rio Jacuí, Rio Grande do Sul, Brazil. The new species also belongs to the Austrolebias alexandri species-group.

\footnotetext{
${ }^{1}$ Departamento de Zoologia, Universidade Federal do Rio Grande do Sul, Av. Bento Gonçalves 9500, 91501-970 Porto Alegre, RS, Brazil. julianoferrer@bol.com.br; malabarb@ufrgs.br

${ }^{2}$ Laboratório de Ictiologia Geral e Aplicada, Departamento de Zoologia, Universidade Federal do Rio de Janeiro, P. O. Box 68049, 21944970 Rio de Janeiro, RJ, Brazil. wcosta@acd.ufrj.br
} 




Fig. 1. Austrolebias paucisquama, holotype, MCP 41879, male, 34.2 mm SL, Rio Grande do Sul, São Sepé, temporary pool close to BR290 highway (30²2'27'S 5333'42'”W), rio Vacacaí drainage.

\section{Material and Methods}

Counts and measurements follow Costa (1995). All measurements are presented as percents of Standard Length (SL), except subunits of head presented as percents of Head Length. All radial elements are included in fin rays counts. Osteological observations were made in specimens cleared and stained (c\&s) according to the method described in Taylor \& Van Dyke (1985). Rostral squamation pattern is described according to Hoedeman (1958) and cephalic neuromasts according to Costa (2001). Examined specimens belong to the following institutions: MCP - Museu de Ciências e Tecnologia, Pontifícia Universidade Católica do Rio Grande do Sul; UFRGS - Departamento de Zoologia, Universidade Federal do Rio Grande do Sul; UFRJ - Universidade Federal do Rio de Janeiro.

\section{Results}

\section{Austrolebias paucisquama, new species}

Figs. 1 - 3

Holotype. MCP 41879, male, 34.2 mm SL, Brazil, Rio Grande do Sul, São Sepé, temporary pool close to BR-290 highway (30²2'27’S 53³3’42”W), rio Vacacaí drainage, rio Jacuí tributary, 15 Sep 2004, J. Anza, J. Giora \& A. Pereira.

Paratypes. Brazil: Rio Grande do Sul: UFRJ 6522, 5 males (1 c\&s), 25.2-27.7 mm SL, 5 females (1 c\&s), 25.6-34.0 mm SL; MCP 41880, 12 males (2 c\&s), 22.4-31.7 mm SL, 14 females (1 c\&s), 18.8-34.8 mm SL; and UFRGS 9354, 3 males (3 c\&s), 22.1-24.9 mm SL, collected with the holotype. UFRGS 9355, 6 males, 21.0-28.5 mm SL, 1 female, $21.4 \mathrm{~mm}$ SL, same locality of the holotype, 9 Jun 2005, J. Ferrer, J. Giora, R. Hirano \& D. Rocha.

Diagnosis. The dark gray pectoral fins combined with the bright blue iridescence in males distinguishes $A$. paucisquama

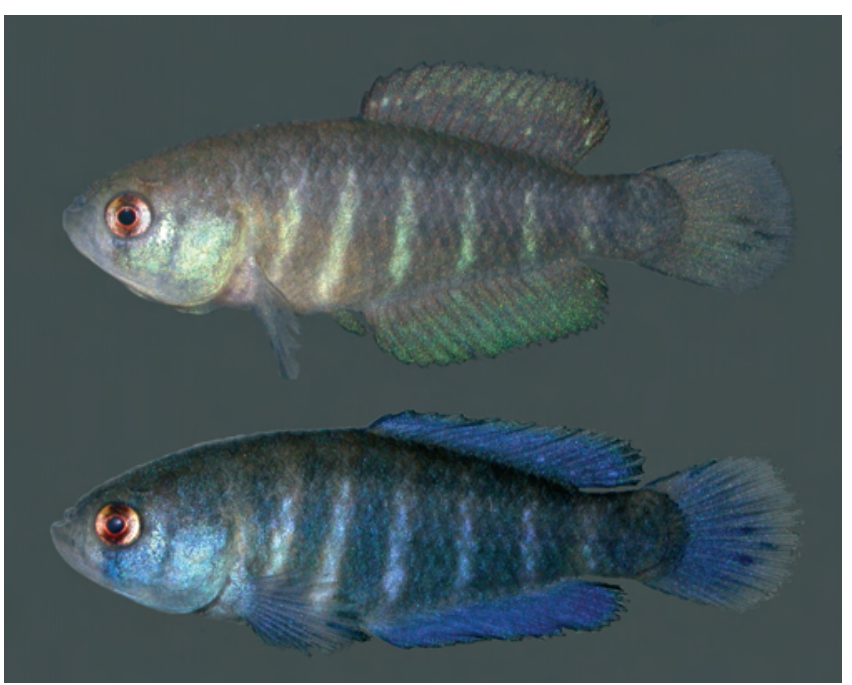

Fig. 2. Austrolebias paucisquama, paratype, MCP 41880, male 25.5 mm SL, Rio Grande do Sul, São Sepé, temporary pool close to BR290 highway (30²2'27”'S, 53³3’42”W), rio Vacacaí drainage. Same specimen alive (above) and just after fixation in formalin (below). 


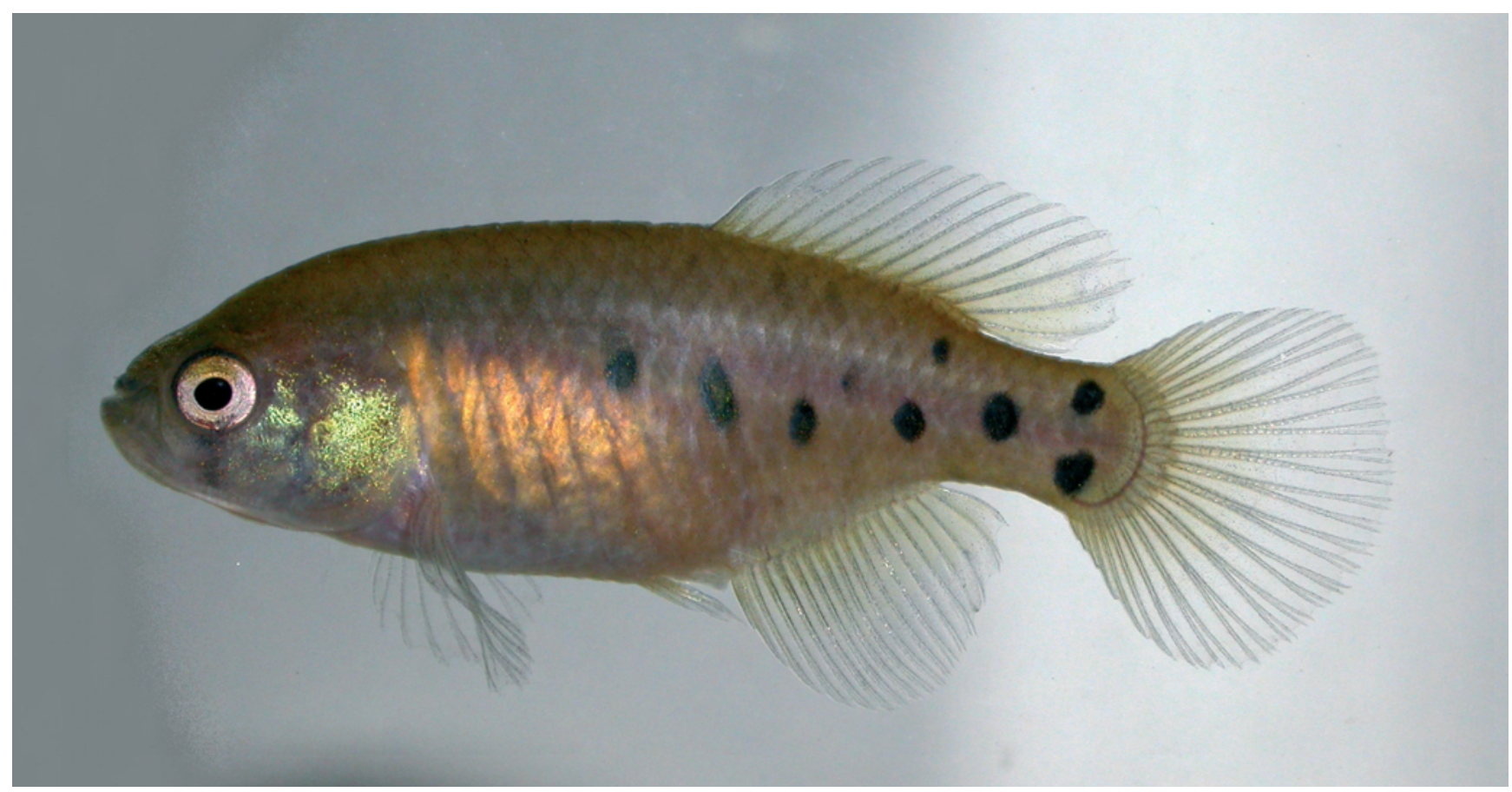

Fig. 3. Austrolebias paucisquama, paratype, MCP 41880, female 32.6 mm SL, Rio Grande do Sul, São Sepé, temporary pool close to BR290 highway (30²2’27”S 53॰33’42”W), rio Vacacaí drainage.

from other species of the genus Austrolebias, except from those of the A. alexandri species-group. The fewer scales around caudal peduncle (12 vs. 16 or more) and the fewer dorsal-fin rays in males (17-21 vs. 20 or more in A. litzi and $A$. nigripinnis; 21 or more in A. affinis, A. alexandri, A. cyaneus, A. juanlangi and A. luzardoi; 22 or more in A. duraznensis, $A$. ibicuiensis, A. paranaensis, A. periodicus) distinguish A. paucisquama from other species of the A. alexandri speciesgroup. The lack of contact organs on the inner surface of the pectoral fin in males and the color pattern of females - ground color light brownish, sides of body with a variable number of relatively large dark black spots distributed mostly on posterior portion of body - distinguish A. paucisquama from all other species of the genus.

Description. Morphometric data on Table 1. Largest male 34.2 mm SL; largest female $34.8 \mathrm{~mm}$ SL. Body compressed. Dorsal head profile slightly concave, more evident in females. Dorsal profile convex from nape to insertion of last dorsal-fin ray. Ventral profile concave from lower jaw to last anal-fin ray

Table 1. Morphometric data of Austrolebias paucisquama. Ranges presented for males include the holotype. $\mathrm{n}=$ number of specimens.

\begin{tabular}{|c|c|c|c|c|c|c|c|c|c|}
\hline & & \multicolumn{4}{|c|}{ Males } & \multicolumn{4}{|c|}{ Females } \\
\hline & $\begin{array}{c}\text { Holotype } \\
\text { MCP } 41879\end{array}$ & $\mathrm{n}$ & Low & High & Mean & $\mathrm{n}$ & Low & High & Mean \\
\hline Standard length $(\mathrm{mm})$ & 34.2 & 23 & 21.0 & 34.2 & 26.5 & 19 & 19.7 & 34.8 & 27.3 \\
\hline \multicolumn{10}{|c|}{ Percents of standard length } \\
\hline Body depth & 34.2 & 23 & 27.1 & 34.5 & 31.8 & 19 & 28.6 & 35.0 & 31.4 \\
\hline Caudal peduncle length & 14.3 & 23 & 11.9 & 15.6 & 13.7 & 19 & 11.3 & 14.8 & 13.0 \\
\hline Predorsal length & 51.3 & 23 & 43.9 & 54.0 & 50.7 & 19 & 54.8 & 61.5 & 58.4 \\
\hline Prepelvic length & 48.3 & 23 & 42.6 & 48.7 & 45.9 & 19 & 48.6 & 54.2 & 51.0 \\
\hline Length of dorsal-fin base & 37.0 & 23 & 32.7 & 41.9 & 37.0 & 19 & 23.2 & 30.6 & 26.3 \\
\hline Length of anal-fin base & 39.5 & 23 & 31.6 & 39.8 & 36.2 & 19 & 19.9 & 25.4 & 22.2 \\
\hline Caudal-fin length & 20.0 & 23 & 18.0 & 27.6 & 21.2 & 19 & 17.0 & 25.6 & 20.5 \\
\hline Pectoral-fin length & 18.5 & 23 & 11.7 & 22.7 & 18.2 & 19 & 15.0 & 22.5 & 18.3 \\
\hline Pelvic-fin length & 10.0 & 23 & 6.3 & 11.0 & 9.2 & 19 & 8.7 & 12.0 & 10.5 \\
\hline Head length & 29.8 & 23 & 28.4 & 32.7 & 30.5 & 19 & 27.6 & 31.8 & 30.2 \\
\hline Head depth & 28.0 & 23 & 24.3 & 30.0 & 27.3 & 19 & 23.7 & 28.6 & 26.4 \\
\hline Head width & 18.5 & 23 & 15.7 & 21.1 & 18.7 & 19 & 18.2 & 21.5 & 20.2 \\
\hline \multicolumn{10}{|c|}{ Percents of head length } \\
\hline Eye diameter & 25.5 & 23 & 24.8 & 33.0 & 28.0 & 19 & 21.7 & 30.9 & 27.7 \\
\hline Snout length & 31.3 & 23 & 21.1 & 34.0 & 27.1 & 19 & 22.3 & 28.0 & 25.4 \\
\hline
\end{tabular}


insertion. Dorsal and ventral profiles of caudal peduncle nearly straight. Maximum body width at least 2.21 in maximum body depth. Greatest body depth at pelvic-fin insertion. Snout blunt. Jaws short.

Dorsal and anal fins rounded. Anterior anal-fin rays in females prolonged forming anterior lobe; in males all anal-fin rays with approximately same length and not forming lobes. Anal-fin origin just posterior or just anterior to dorsal-fin origin in males; posterior to dorsal-fin origin, at vertical through base of second to fourth dorsal-fin rays in females. Base of dorsal-fin origin at vertical between 8th and 9th pleural ribs in males and between 11th and 12th pleural ribs in females. Base of anal-fin origin at vertical between 8th and 9th pleural ribs in males and between 12th and 13th pleural ribs in females. Urogenital papilla not attached to anal fin. Caudal fin rounded. Pectoral fins elliptical, posterior margin on vertical between urogenital papilla and base of 2nd anal-fin ray in males, reaching or almost reaching pelvic-fin base in females. Tip of each pelvic fin reaching base of $2^{\text {nd }}$ or $3^{\text {rd }}$ anal-fin rays in males, between urogenital papilla and base of 1st anal-fin ray in females. Pelvic-fin bases in close proximity, medial membrane not united. Dorsal-fin rays 17-21 in males and 15-21 in females. Anal-fin rays 19-23 in males and 17-19 in females. Caudal-fin rays 23-27, usually 25. Pectoral-fin rays 11, rarely 12 . Pelvic-fin rays 4-5.

Scales large and cycloid. Trunk and head scaled, except ventral surface of head. No scales on dorsal and anal-fin bases, and two rows of scales on caudal-fin base. Frontal squamation H-patterned. Longitudinal series of scales 25-26, regularly arranged; transversal series of scales 11-13; scale rows around caudal peduncle 12. Minute contact organ on each scale of anteroventral portion of flank in males. No contact organs on fins.

Cephalic neuromasts: supraorbital 15-21, parietal 1, anterior rostral 1, posterior rostral 1, infraorbital 24-28, preorbital 2 , otic 1-2, post-otic $1-3$, supratemporal 1 , median opercular 1 , ventral opercular 2, preopercular 19-22, mandibular 8-11, lateral mandibular 4-6. Six branchiostegal rays. Gill-rakers on first branchial arch 2+8. Total vertebrae 28-30.

Life coloration in males. Ground color dark gray. Sides of body with 6,7 or rarely 8 iridescent greenish-blue vertical bars, two or three times narrower than space between each pair of bars, and not extended to dorsum. Urogenital papilla gray. Opercular and infraorbital regions greenish-blue, with vertical and near rectangular dark bar below eye and small dark grayish triangular spot dorsoposterior to eye not reaching parietal neuromasts. Iris white anteriorly and posteriorly; red and black pigmented vertical bar crossing center of eye. Dorsal and anal fins iridescent greenish-blue, sometimes with light spots; usually grayish near fins base. Caudal fin iridescent greenish-blue, except at distal portion. Pelvic and pectoral fins bright iridescent blue. Distal border of dorsal, anal, pectoral and pelvic fins black pigmented (Fig. 1).

Color in males just after fixation in formalin. Color pattern of bars and spots basically same in life and just fixed specimens. General body color, however, changes drastically. Red pigments do not change, but iridescent greenish-blue pigments become very intense blue, giving general dark blue appearance to fish (Fig. 2).

Life coloration in females. Ground color light brownish. Sides of body with variable number of relatively large dark black spots, distributed mostly on posterior portion of body. Purple line discernible approximately on distal border of hypural fan. Belly golden in all observed females. Urogenital papilla light. Opercular region, and sometimes infraorbital region bright green, with vertical and narrow dark bar below eye. Iris white anteriorly and posteriorly, and black pigmented below and above the pupil. All fins hyaline (Fig. 3).

Distribution. Known only from the type-locality, a temporary pool in the rio Vacacaí drainage, rio Jacuí tributary, laguna dos Patos drainage (Fig. 4).

Habitat. The type locality consists of a small temporary pool located close to the BR290 highway, and distant from any permanent freshwater flow in the altitude of $154 \mathrm{~m}$ (Fig. 5). The specimens of Austrolebias paucisquama were the only

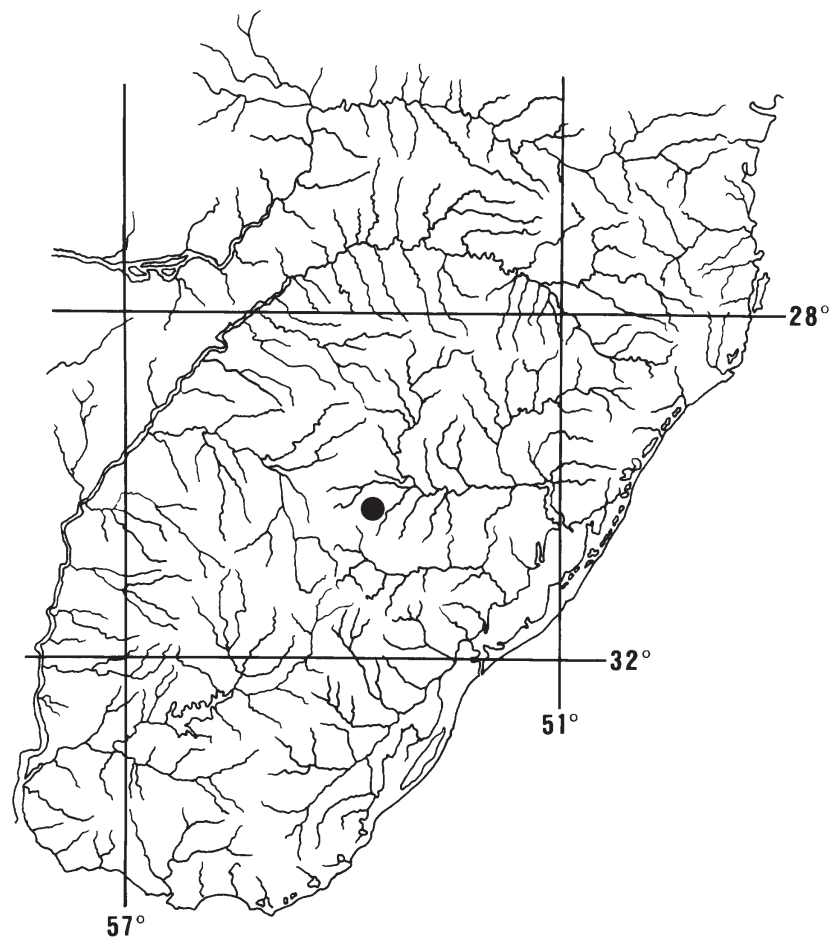

Fig. 4. Southern Brazil and Uruguay, showing the type locality (black circle) of Austrolebias paucisquama. 


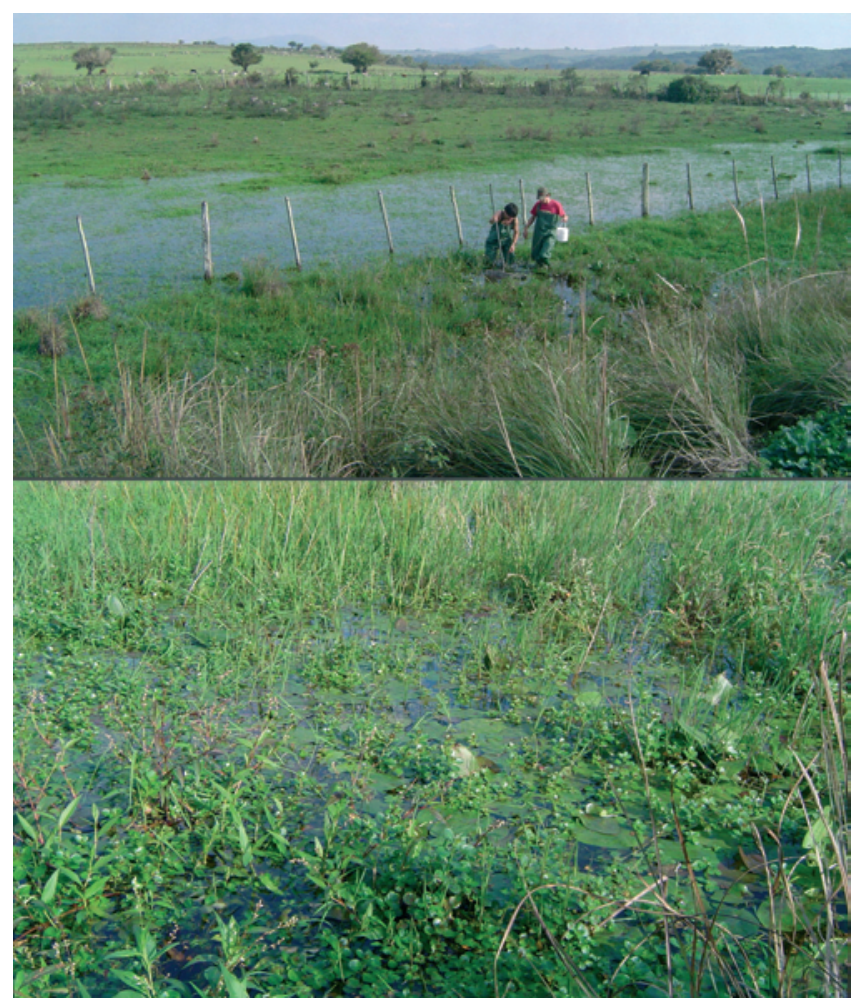

Fig. 5. Temporary pool close to BR290 highway (30²2’27’'S $53^{\circ} 33^{\prime} 42^{\prime \prime} \mathrm{W}$ ), type locality of Austrolebias paucisquama (above) and detailed image of the vegetation coverage.

fishes collected in two collecting efforts in September 2004 and June 2005, corresponding to winter and autumn in the southern hemisphere. Maximum depth observed was $50 \mathrm{~cm}$. The environment was almost completely covered with emergent vegetation, serving as cattle pasture.

Etymology. From the Latin "pauci" meaning few, and "squama" meaning scales, in reference to the reduced number of scales around caudal peduncle. A name in apposition.

\section{Discussion}

Austrolebias species are among the most endangered fish species in the state of Rio Grande do Sul, Brazil. Eleven species of Austrolebias (one of these previously listed in the genus Megalebias) are listed in the Red Book of endangered species from the Rio Grande do Sul (Fontana et al., 2003), corresponding to $39 \%$ of the fish species endangered in that state. This is mostly related to the high endemism showed by these species and the fact their preferential environments suffer high impact by human use, mostly in agricultural activities.

The new species belongs to the A. alexandri species- group, by sharing the apomorphic bright blue iridescence and pectoral fins dark gray in males. However, A. paucisquama is easily distinguished from all species of the genus by the lack of contact organs in the pectoral fins of males, the reduced number of scales around caudal peduncle, the reduced number of dorsal-fin rays in males and the color pattern of females.

Most Austrolebias species inhabit lowlands and inundated areas adjacent to permanent waters, in altitudes usually lower than $150 \mathrm{~m}$ (Costa et al., 2004). These species seem to have larger areas of distribution (e.g. A. alexandri, A. elongatus, A. gymnoventris, A. luteoflammulatus, A. monstrosus, A. prognathus, A. vazferrerae, A. wolterstorffi, see Costa, 2006). So far A. paucisquama has been recorded only from a temporary pool, without the proximity of a permanent water flow, in the altitude of $154 \mathrm{~m}$ and close to an area of extensive use as pasture. This situation places the new species as a critically endangered species of Austrolebias.

\section{Acknowledgments}

The authors thank Juan Anza, Júlia Giora and Adriana Saccol Pereira that first collected the new species and Conselho Nacional de Desenvolvimento Científico e Teconológico - CNPq, Brazil (proc. 478002/2006-8 and 476821/ 2003-7) for support.

\section{Literature Cited}

Costa, W. J. E. M. 1995. Pearl killifishes - the Cynolebiatinae: systematics and biogeography of the neotropical annual fish subfamily. Neptune City, TFH Publications, 128p.

Costa, W. J. E. M. 2001. The neotropical annual fish genus Cynolebias (Cyprinodontiformes: Rivulidae): phylogenetic relationships, taxonomic revision and biogeography. Ichthyological Exploration of Freshwaters, 12(4): 333-383.

Costa, W. J. E. M. 2002. The Austrolebias alexandri species group: a taxonomical revision of an annual fish clade (Cyprinodontiformes: Rivulidae) in southern Brazil. Comunicações do Museu de Ciências e Tecnologia da PUCRS, sér. Zool., 15(1): 87-111.

Costa, W. J. E. M. 2006. The South American annual killifish genus Austrolebias (Teleostei: Cyprinodontiformes: Rivulidae): phylogenetic relationships, descriptive morphology and taxonomic revision. Zootaxa, 1213: 1-162.

Costa, W. J. E. M., R. E. Reis \& E. Behr. 2004. Austrolebias varzeae, a new annual fish from the upper rio Uruguay basin, southern Brazil (Cyprinodontiformes: Rivulidae). Neotropical Ichthyology, 2(1): 13-17.

Fontana, C. S., G. A. Bencke \& R. E. Reis. 2003. Livro vermelho da fauna ameaçada de extinção no Rio Grande do Sul. Porto Alegre, Edipucrs, 632p.

Hoedeman, J. J. 1958. The frontal scalation pattern in some groups 
of toothcarps (Pisces, Cyprinodontiformes). Bulletin of Aquatic Biology, 1: 23-28.

Perujo, E., P. A. Calviño, H. Salvia \& F. Prieto. 2005. Austrolebias luzardoi (Cyprinodontiformes: Rivulidae), una especie nueva de pez anual de la cuenca del río Cuareim, República Oriental del Uruguay. Revista del Museu de La Plata, 17(171): 1-12.

Taylor, W. R. \& G. C. Van Dyke. 1985. Revised procedures for staining and clearing small fishes and other vertebrates for bone and cartilage study. Cybium, 9: 107-119.

Accepted May 2008 Published June 28, 2008 